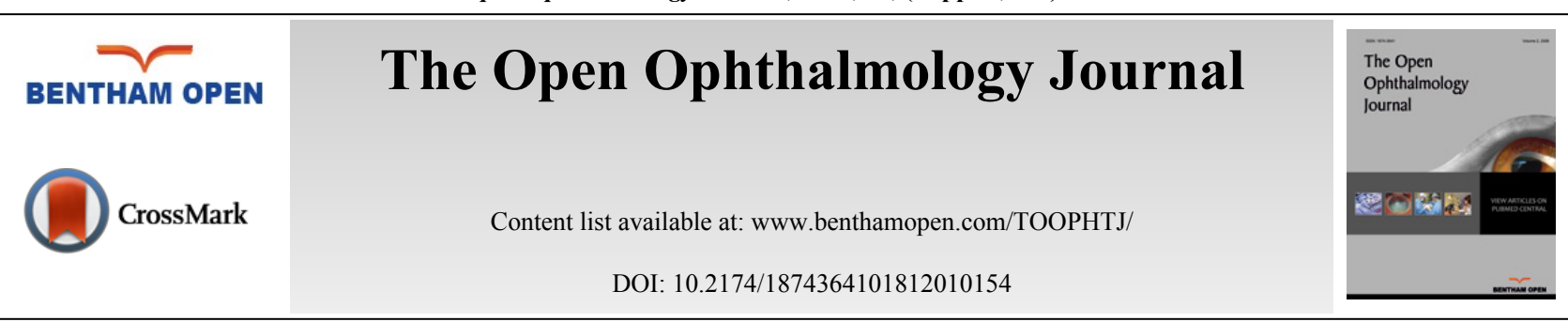

REVIEW ARTICLE

\title{
Perspective of Future Potent Therapies for Fuchs Endothelial Corneal Dystrophy
}

\author{
Naoki Okumura, Ryousuke Hayashi and Noriko Koizumi* \\ Department of Biomedical Engineering, Faculty of Life and Medical Sciences, Doshisha University, Kyotanabe, Japan
}

Received: September 12, 2017

Revised: December 16, 2018

Accepted: January 30, 2018

\begin{abstract}
:
Background:

Fuchs Endothelial Corneal Dystrophy (FECD) is a progressive disease that affects the corneal endothelium in both eyes. Recent studies have identified a novel genetic basis for FECD, and basic research findings have provided evidence for its underlying pathophysiology. Since its first description by Ernst Fuchs in 1910, the only therapeutic choice has been corneal transplantation using donor corneas. However, accumulating evidence suggests that a change in this "rule" may be imminent.
\end{abstract}

\section{Conclusions:}

This article reviews the current knowledge of the genetics and pathophysiology of FECD, and it introduces some potent therapeutic modalities that show promise as new treatments for this disorder.

Keywords: FECD, ECM, Endothelial Corneal Dystrophy, TCF4, SNP, ICD3.

\section{INTRODUCTION}

Fuchs Endothelial Corneal Dystrophy (FECD) is a progressive disease that affects the corneal endothelium in both eyes. The hallmarks of FECD in the clinical setting are the formation of excrescences, called guttae, on Descemet's membrane and the loss of corneal endothelial cells. FECD shows a gender dichotomy, with a female to male ratio of 2.5:1 to 3:1. FECD typically occurs at the age of 40-50, and it progresses to an advanced stage in some, but not all, patients. In the advanced stage, decompensation of the corneal epithelium disrupts the water balance in the corneal stroma, which induces edema of the corneal stroma and epithelium and causes severe vision loss [1]. Even in patients without corneal edema, the formation of guttae and the thickening of the Descemet's membrane due to accumulation of Extracellular Matrix (ECM) components results in forward light scatter and a loss of vision quality $[2,3]$.

Recent studies have indicated an association between a novel genetic pattern and the development of FECD. In addition, basic research studies are now beginning to reveal the underlying pathophysiology of this disease. Despite these advances in understanding the nature of FECD, the only therapeutic choice for its treatment remains corneal transplantation using donor corneas-the original treatment used when Ernst Fuchs first described this disease in 1910 [1]. However, accumulating evidence now indicates that important changes are imminent regarding the treatment of FECD. This article provides a review of the current knowledge of the genetics and pathophysiology of FECD, and it introduces some potent therapeutic modalities that show promise as new treatments for FECD.

\section{METHODS}

Literature searches were performed in PubMed (https:// www.ncbi.nlm.nih.gov/ pubmed) and ClinicalTrials.gov

* Address correspondence to this author at the Department of Biomedical Engineering, Faculty of Life and Medical Sciences, Doshisha University, 1-3 Tatara Miyokodani, Kyotanabe Kyoto, Japan, Tel: +81-774-65-6125; E-mail: nkoizumi@mail.doshisha.ac.jp 
(https://clinicaltrials.gov/). Key search terms were the references cited in each eligible article that included "Fuchs endothelial corneal dystrophy," "TCF4," "single nucleotide polymorphism, SNPs, or polymorphism." This review is not a meta-analysis; therefore, we selected literature that allowed us to introduce future perspectives as well as to summarize the current status of this research topic.

\section{GENETICS}

Studies of familial FECD cases show that the disease has an autosomal dominant inheritance pattern [4]. However, a certain proportion of patients with FECD have sporadic disease, without a familial history. The ICD3 classification categorizes FECD patients as those with: 1) early-onset FECD, 2) identified genetic loci, and 3) disease without known inheritance [5].

Early-onset FECD is a rare form, and these patients exhibit corneal edema by the age of 30-40. Genetic screening of a family with early-onset FECD identified a missense mutation of the COL8A2 gene that resulted in substitution of a lysine for a glutamine (Q455K) on chromosome $1 \mathrm{p} 34.3-\mathrm{p} 32$. Analysis of large families with a common form of lateonset FECD also showed a significant linkage between the FCD1, FCD2, FCD3, and FCD4 loci on chromosomes 13, 18, 5, and 9, respectively [6 - 9]. Four genes ( $L C A 411, T C F 8, L O X H D 1$, and $A G B L 1)$ were reported as causal genetic mutations, although these genetic mutations were rarely identified in patients with FECD [9 - 14].

Researchers have since devoted their efforts to identify a genetic cause for the large proportion of patients with FECD. For example, a Genome-Wide Association Study (GWAS), conducted by Baratz and colleagues in 2010, identified a significant association between late-onset FECD and the intronic Single Nucleotide Polymorphism (SNPs) rs613872 in Transcription Factor 4 (TCF4) [15]. Similarly, replication studies have shown a strong association between rs613872 and FECD, mainly in Caucasian cohorts [16, 17]. Other SNPs in TCF4, apart from rs613872, were associated with FECD in populations from Singapore, Southern China, and India, suggesting the occurrence of ethnic variations in the SNPs in TCF4 [18 - 20].

In 2012, Wieben and colleagues reported the discovery of an expanded CTG trinucleotide repeat in intron 3 of TCF4 in patients with FECD [21]. Their investigation of 66 FECD cases and 63 unaffected controls demonstrated a sensitivity and specificity of $79 \%$ and $96 \%$, respectively, for more than 50 repeats identifying FECD; this specificity was higher than that previously reported for the rs613872 SNP. The percentages of patients with FECD that harbored the CTG trinucleotide repeat expansion varied with their ethnicities; however, this strong association was replicated in multiple ethnic groups (Table 1) [20, 22 - 27].

Table 1. Summary of previous reports of CTG trinucleotide repeat expansion in TCF4.

\begin{tabular}{|c|c|c|c|c|c|c|c|c|}
\hline- & Wieben ED [21] & Mootha VV [22] & Xing C [23] & Nanda GG [20] & Vasanth S [24] & Nakano M [25] & Foja S [26] & Kuot A [27] \\
\hline Population & Caucasian & Caucasian & Chinese & Indian & - & Japanese & German & Australian \\
\hline $\begin{array}{c}\text { Cases } \\
(\mathrm{FECD})\end{array}$ & 66 & 120 & 57 & 44 & 574 & 47 & 61 & 189 \\
\hline Controls & 63 & 100 & 121 & 108 & 354 & 96 & 113 & 183 \\
\hline $\begin{array}{c}\mathrm{CTG} \geq 40 \text { or } 50 \\
(\mathrm{FECD})\end{array}$ & $\begin{array}{c}79 \% \\
(\mathrm{CTG} \geq 50)\end{array}$ & $\begin{array}{c}73 \% \\
(\mathrm{CTG} \geq 40)\end{array}$ & $\begin{array}{c}44 \% \\
(\mathrm{CTG} \geq 40)\end{array}$ & $\begin{array}{c}34 \% \\
(\mathrm{CTG} \geq 50)\end{array}$ & $\begin{array}{c}62 \% \\
(\mathrm{CTG} \geq 40)\end{array}$ & $\begin{array}{c}26 \% \\
(\mathrm{CTG} \geq 50)\end{array}$ & $\begin{array}{c}77 \% \\
(\mathrm{CTG}>50)\end{array}$ & $\begin{array}{c}51 \% \\
(\mathrm{CTG} \geq 40)\end{array}$ \\
\hline $\begin{array}{c}\mathrm{CTG} \geq 40 \text { or } 50 \\
(\mathrm{Control})\end{array}$ & $\begin{array}{c}3 \% \\
(\mathrm{CTG} \geq 50)\end{array}$ & $\begin{array}{c}7 \% \\
(\mathrm{CTG} \geq 40)\end{array}$ & $\begin{array}{c}2 \% \\
(\mathrm{CTG} \geq 40)\end{array}$ & $\begin{array}{c}5 \% \\
(\mathrm{CTG} \geq 50)\end{array}$ & $\begin{array}{c}4 \% \\
(\mathrm{CTG} \geq 40)\end{array}$ & $\begin{array}{c}0 \% \\
(\mathrm{CTG} \geq 50)\end{array}$ & $\begin{array}{c}12 \% \\
(\mathrm{CTG}>50)\end{array}$ & $\begin{array}{c}5 \% \\
(\mathrm{CTG} \geq 40)\end{array}$ \\
\hline
\end{tabular}

\section{PATHOPHISIOLOGY}

\subsection{The Unfolded Protein Response}

Under normal conditions, proteins undergo folding in the lumen of the Endoplasmic Reticulum (ER), and correctly folded proteins are then packaged into ER exit vesicles for delivery to membranes for extracellular secretion. By contrast, improperly folded proteins are removed in the proteasome through the process known as ER-Associated Degradation (ERAD) [28 - 30]. However, impairment of homeostasis induces ER stress, which disrupts ERAD and triggers apoptosis to remove rogue cells that accumulate unfolded proteins [31,32]. This highly regulated process is called the Unfolded Protein Response (UPR), and the UPR is involved in the pathogenesis of various diseases, including Alzheimer's disease, Parkinson's disease, diabetes mellitus, multiple myeloma, and retinitis pigmentosa [33 38]. 
In 2010, Engler and colleagues postulated that activation of the UPR plays a central role in the pathogenesis of FECD through the induction of apoptosis in corneal endothelial cells [39]. They showed an increased and dilated ER structure and upregulation of the markers of the UPR in the corneal endothelium of patients with FECD [39]. The same research group subsequently showed that homozygous knock-in of Col8a2 $2^{\text {Q455K/Q455K}}$, a causal gene for early-onset FECD, was sufficient to induce FECD-like ocular features in mice, and these changes were linked with UPR-associated apoptosis [40]. Recently, our group showed that ECM components, such as type I collagen and fibronectin, form aggregates of unfolded proteins in the corneal endothelium of FECD patients [41]. We also showed that activation of transforming growth factor- $\beta$ (TGF- $\beta$ ) signaling causes a chronic overload of ECM proteins within the ER, which induces an accumulation of unfolded protein and activation of the intrinsic apoptotic pathway through the UPR [42]. The genetic background underlying the UPR induction is not yet elucidated; however, accumulating evidence supports a role for the UPR and associated apoptosis in FECD.

\subsection{Oxidative Stress and Mitochondrial Dysfunction}

Much research has confirmed an involvement of oxidative stress in the pathogenesis of FECD, and a linkage between mitochondrial dysfunction and the generation of oxidative stress is suggested [43 - 47]. For instance, an early study indicated that the numbers of mitochondria were decreased in parallel with downregulation of cytochrome oxidase [48]. Serial analysis of gene expression revealed that expression of mitochondrial antioxidant genes was diminished in the corneal endothelium of patients with FECD [49]. Jurkunas and colleagues demonstrated that an oxidant-antioxidant imbalance leads to oxidative DNA damage and apoptosis [44]. Very recently, Benischke and colleagues reported that constitutive activation of mitophagy causes a reduction in mitochondrial mass and depletion of the numbers of functional mitochondria [50]. Accumulating evidence suggests that oxidative stress, induced by mitochondrial dysfunction, damages corneal endothelial cells. Interestingly, ER stress activates the intrinsic apoptotic pathway (the mitochondrial pathway) in the corneal endothelium, as it does in other cell types [41]. Future studies will likely elucidate the nature of the involvement of both ER stress and oxidative stress in the pathogenesis of FECD.

\subsection{RNA Foci}

In 2015, Du and colleagues reported that the corneal endothelial cells of patients with FECD harbor poly $(\mathrm{CUG})_{\mathrm{n}} \mathrm{RNA}$, and this results in the formation of RNA foci. They also suggested that RNA toxicity and missplicing play an important role in the pathogenesis of FECD, similar to that played in myotonic dystrophy type 1, a trinucleotide repeat expansion disease [51]. Mootha and colleagues also identified RNA foci in the corneal endothelium of subjects with FECD who showed trinucleotide repeat expansion in TCF4, but these foci were absent from the corneal endothelium of subjects with FECD but without this trinucleotide repeat expansion [52].

\section{FUTURE TREATMENTS}

\subsection{Current Therapy}

Corneal transplantation using donor corneas is currently the only therapy for treating corneal endothelial decompensation diseases, including FECD. Penetrating keratoplasty, in which a full-thickness patient cornea is replaced with full-thickness donor cornea, has been performed since 1906. New surgical procedures, such as Descemet's Stripping Endothelial Keratoplasty (DSEK) and Descemet's Membrane Endothelial Keratoplasty (DMEK), selectively replace the diseased corneal endothelial layer with a lamellar donor graft that includes the corneal endothelium. These lamellar surgeries have advantages over penetrating keratoplasty, and their use has therefore spread explosively [53].

\subsection{Tissue Engineering Therapy}

The evolution of corneal transplantation procedures now enables less invasive treatment with better clinical outcomes, but problems remain. The most serious are the shortage of donor corneas, the difficulty of the surgical procedure, and the incidence of graft failure in acute and chronic phases. These issues have motivated researchers to devise tissue engineering treatments that can overcome the current transplantation limitations [53, 54].

Two strategies adopt the use of transplanted cultured corneal endothelial cells as regenerative medicine: 1) transplantation of a cultured corneal endothelial sheet by a procedure resembling DSEK or DMEK and 2) direct injection of cultured corneal endothelial cells, without a carrier, into the anterior chamber [55]. The sheets used in transplantation are produced by culturing corneal endothelial cells on a number of different substrates, such as collagen, amniotic membrane, and human corneal stroma, and animal experiments have confirmed that the transplantation of the 
resulting sheet enables the regeneration of a transparent cornea [56 - 59]. However, to the best of our knowledge, the transplantation of cultivated corneal endothelial sheets has not yet been introduced into the clinical setting.

Some research groups, including ours, have attempted to regenerate corneal endothelium directly by injecting cultured corneal endothelial cells into the anterior chamber without a carrier [60 - 62]. However, animal experiments have revealed that an insufficient number of the injected cells adhere to the back side of the cornea, so that a corneal endothelium fails to regenerate in vivo. Our previous research indicated that cell adhesion is inhibited by the activation of Rho/ROCK signaling, and conversely, inhibition of this signaling pathway by a Rho kinase (ROCK) inhibitor enhances cell adhesion. Therefore, we applied a ROCK inhibitor to promote engraftment [63,64]. We confirmed, using rabbit and monkey corneal endothelial dysfunction models, that coinjection of cultured corneal endothelial cells and a ROCK inhibitor into anterior chamber resulted in the regeneration of the corneal endothelium $[64,65]$.

In 2013, after obtaining the approval from the Japanese Ministry of Health, Labour, and Welfare, we initiated a clinical trial (Clinical trial registration: UMIN000012534) at the Kyoto Prefectural University of Medicine to evaluate this cell injection therapy as a treatment for corneal endothelial dysfunction [66]. Our preliminary clinical data have confirmed that coinjection of cultured corneal endothelial cells and a ROCK inhibitor regenerates the corneal endothelium and restores a transparent cornea in human subjects. Further clinical data are necessary, but cell-based therapy appears to be a potent future treatment for corneal endothelial decompensation diseases, including FECD.

\subsection{ROCK Inhibitor Eye Drops}

Rho is a small GTPase, and RhoA activates ROCK, a serine/threonine kinase that phosphorylates various substrates. ROCK signaling plays an essential role in several fundamental cellular events, such as cell adhesion, motility, proliferation, differentiation, and apoptosis [67 - 69]. In 2009, we reported that inhibition of ROCK signaling promotes the in vitro proliferation of corneal endothelial cells [63]. Subsequently, we found that administration of a ROCK inhibitor in eye drop form promotes wound healing in the corneal endothelium in rabbit and monkey models [70 - 72].

We have since conducted pilot clinical research to investigate the use of topically applied ROCK inhibitor eye drops in patients who have undergone central corneal endothelium removal by transcorneal freezing. Our findings suggested that the eye drop form of ROCK inhibitor is a potent therapeutic treatment choice for patients with early-stage FECD $[71,73]$. Notably, one 52-year-old male patient diagnosed with late-onset FECD recovered full corneal transparency after transcorneal freezing and the use of ROCK inhibitor eye drops. His central corneal thickness was reduced from $703 \mu \mathrm{m}$ to $568 \mu \mathrm{m}$ and his visual acuity improved from $20 / 63$ to $20 / 20$. His corneal transparency was maintained for more than 6 years, and the original plans for an eventual corneal transplantation were canceled [73].

Recent investigations have examined the effect of surgical removal of the central Descemet's membrane, including pathological corneal endothelium [74 - 76], and one clinical study has indicated a positive effect of combining ROCK inhibitor eye drops with this procedure [77]. However, clinical data for the usefulness of ROCK inhibitors in FECD treatment remain limited, so randomized clinical trials are still needed before adoption of this eye drop as a routine therapeutic option.

\subsection{Potent Pharmaceutical Agents}

Stealth BioTherapeutics (Newton, MA) has been developing drug candidates for targeting diseases associated with mitochondrial dysfunction. They initiated a phase 2 clinical trial of elamipretide in eye drop form, with the expectation that this drug would target the inner mitochondrial membrane to help preserve mitochondrial energetics (http://www.stealthbt.com/). The results of this clinical trial have not yet been released, but elamipretide is currently the most advanced-stage pharmaceutical aimed at the treatment of FECD.

Kim and colleagues reported that N-Acetylcysteine (NAC), a thiol-containing antioxidant and radical scavenger, rescued cultured corneal endothelial cells from damage mediated by ER and oxidative stress [78]. They also demonstrated that systemic use of NAC suppressed the progression of FECD in early-onset FECD model mice $\left(\right.$ Col8a $2^{\text {Q455K/Q455K }}$ ), thereby providing an in vivo proof of concept of the use of NAC as a potent therapeutic candidate for treatment of FECD [78]. The same research group also showed that the addition of lithium further increased the survival of cultured corneal endothelial cells when ER and oxidative stresses were triggered [79]. A higher corneal endothelial cell density was also maintained in early-onset FECD model mice given a lithium treatment than in a non-treatment group [79]. The researchers suggested that lithium increases the survival of corneal endothelial cells by an upregulation of autophagy; therefore, lithium may represent a new therapeutic agent for the treatment of FECD [79]. 
More recently, the same group attempted a drug screening based on the postulated FECD pathophysiology involving ER and oxidative stresses and cell death [80]. They induced ER stress with thapsigargin and oxidative stress with hydrogen peroxide in cultured corneal endothelial cells, and then screened 640 compounds found in the Food and Drug Administration (FDA)-approved drug library. They reported that oxotremorine and mefenamic acid were potential survival factors that overcame stress-related cell death.

Our group has reported that activation of TGF- $\beta$ signaling activates genes that induce the epithelial-mesenchymal transition (EMT). These include ZEBI and SNAI1, and their induction results in the accumulation of ECM components [81]. This production of ECM components was more strongly upregulated in cell models established from patients with FECD than in control corneal endothelial cells, following exposure of the cells to TGF- $\beta$. We recently reported high expression levels of TGF- $\beta$ isoforms and TGF- $\beta$ receptors in the corneal endothelium of patients with FECD, and we proposed that activation of TGF- $\beta$ signaling induces a chronic overload of ECM components, resulting in apoptosis through the UPR [42]. We also showed that inhibition of TGF- $\beta$ signaling suppressed this accumulation of ECM components and suppressed UPR-mediated apoptosis in cell models established from patients with FECD. These findings suggest that inhibition of TGF- $\beta$ might be a potent therapeutic option [42]. A summary of the proposed drug candidates for treating FECD is shown in Table 2.

Table 2. Proposed drug candidates for treating FECD.

\begin{tabular}{|c|c|c|c|}
\hline Candidate Drugs & Status & Proposed Mechanism & Author or Company \\
\hline Elamipretide & Phase 2 clinical study & Preserves mitochondrial energetics & Stealth BioTherapeutics \\
\hline Rho kinase inhibitor & Pilot clinical research & Promotes cell proliferation & Okumura N, Koizumi N [71, 73] \\
\hline N-acetylcysteine & Animal model & Increases cell survival & Kim EC [78] \\
\hline Lithium & Animal model & Increases cell survival & Kim EC [79] \\
\hline Oxotremorine & in vitro & Increases cell survival & Kim EC [80] \\
\hline Mefenamic acid & in vitro & Increases cell survival & Kim EC [80] \\
\hline TGF- $\beta$ inhibitor & in vitro & Suppresses unfolded protein mediated cell death & Okumura N [42] \\
\hline
\end{tabular}

\section{CONCLUSION}

Corneal transplantation has been the only therapy available for treating FECD for many years. However, recent advancements in tissue engineering techniques may now provide innovative cell-based therapies. "Missing links" still necessitate further investigations, but new information regarding the genetic background and pathophysiology of FECD is rapidly accumulating. Importantly, the recent findings improve the understanding of FECD, but they also guide further investigations aimed at identifying future therapeutic modalities. Indeed, several drug candidates have recently been reported, although none of these drugs has yet been introduced into the market. Corneal transplantations using donor corneas continue to remain the standard treatment, but we believe that the new therapeutic options, such as cellbased therapy and the use of pharmaceutical agents, will provide less invasive and more effective therapies.

\section{CONSENT FOR PUBLICATION}

Not applicable.

\section{CONFLICT OF INTEREST}

Noriko Koizumi is listed as the inventor of the patent regarding the application of the ROCK inhibitor for corneal endothelium regeneration (registration number: 5657252). Noriko Koizumi and Naoki Okumura are listed as inventors of the patent regarding the application of TGF- $\beta$ signal inhibition for treatment of Fuchs endothelial corneal dystrophy.

\section{ACKNOWLEDGEMENT}

This study was supported by the Program for the Strategic Research Foundation at Private Universities from MEXT (Koizumi, N. and Okumura, N.), JSPS KAKENHI Grant Numbers JP16K11307 (Koizumi, N) and JP 15K10885 (Okumura, N.). 


\section{REFERENCES}

[1] Weisenthal R, Streeten B. Descemet's Membrane and Endothelial Dystrophies. Cornea $3^{\text {rd }}$ edition. 2011;1:845-64.

[2] Wacker K, McLaren JW, Amin SR, Baratz KH, Patel SV. Corneal high-order aberrations and backscatter in fuchs' endothelial corneal dystrophy. Ophthalmology 2015; 122(8): 1645-52. [http://dx.doi.org/10.1016/j.ophtha.2015.05.005] [PMID: 26050543]

[3] Watanabe S, Oie Y, Fujimoto H, et al. Relationship between corneal guttae and quality of vision in patients with mild fuchs' endothelial corneal dystrophy. Ophthalmology 2015; 122(10): 2103-9. [http://dx.doi.org/10.1016/j.ophtha.2015.06.019] [PMID: 26189189]

[4] Eghrari AO, Riazuddin SA, Gottsch JD. Fuchs corneal dystrophy. Prog Mol Biol Transl Sci 2015; $134:$ 79-97. [http://dx.doi.org/10.1016/bs.pmbts.2015.04.005] [PMID: 26310151]

[5] Weiss JS, Moller HU, Aldave AJ, et al. IC3D classification of corneal dystrophies-edition 2. Cornea. 2015; 34: pp. (2)117-59.

[6] Sundin OH, Jun AS, Broman KW, et al. Linkage of late-onset Fuchs corneal dystrophy to a novel locus at 13pTel-13q12.13. Invest Ophthalmol Vis Sci 2006; 47(1): 140-5. [http://dx.doi.org/10.1167/iovs.05-0578] [PMID: 16384955]

[7] Sundin OH, Broman KW, Chang HH, Vito EC, Stark WJ, Gottsch JD. A common locus for late-onset Fuchs corneal dystrophy maps to 18q21.2-q21.32. Invest Ophthalmol Vis Sci 2006; 47(9): 3919-26. [http://dx.doi.org/10.1167/iovs.05-1619] [PMID: 16936105]

[8] Riazuddin SA, Eghrari AO, Al-Saif A, et al. Linkage of a mild late-onset phenotype of Fuchs corneal dystrophy to a novel locus at 5q33.1q35.2. Invest Ophthalmol Vis Sci 2009; 50(12): 5667-71.

[http://dx.doi.org/10.1167/iovs.09-3764] [PMID: 19608540]

[9] Riazuddin SA, Zaghloul NA, Al-Saif A, et al. Missense mutations in TCF8 cause late-onset Fuchs corneal dystrophy and interact with FCD4 on chromosome 9p. Am J Hum Genet 2010; 86(1): 45-53. [http://dx.doi.org/10.1016/j.ajhg.2009.12.001] [PMID: 20036349]

[10] Vithana EN, Morgan PE, Ramprasad V, et al. SLC4A11 mutations in Fuchs endothelial corneal dystrophy. Hum Mol Genet 2008; 17(5): 656-66. [http://dx.doi.org/10.1093/hmg/ddm337] [PMID: 18024964]

[11] Riazuddin SA, Vithana EN, Seet LF, et al. Missense mutations in the sodium borate cotransporter SLC4A11 cause late-onset Fuchs corneal dystrophy. Hum Mutat 2010; 31(11): 1261-8.

[http://dx.doi.org/10.1002/humu.21356] [PMID: 20848555]

[12] Mehta JS, Vithana EN, Tan DT, et al. Analysis of the posterior polymorphous corneal dystrophy 3 gene, TCF8, in late-onset Fuchs endothelial corneal dystrophy. Invest Ophthalmol Vis Sci 2008; 49(1): 184-8. [http://dx.doi.org/10.1167/iovs.07-0847] [PMID: 18172091]

[13] Riazuddin SA, Parker DS, McGlumphy EJ, et al. Mutations in LOXHD1, a recessive-deafness locus, cause dominant late-onset Fuchs corneal dystrophy. Am J Hum Genet 2012; 90(3): 533-9. [http://dx.doi.org/10.1016/j.ajhg.2012.01.013] [PMID: 22341973]

[14] Riazuddin SA, Vasanth S, Katsanis N, Gottsch JD. Mutations in AGBL1 cause dominant late-onset Fuchs corneal dystrophy and alter proteinprotein interaction with TCF4. Am J Hum Genet 2013; 93(4): 758-64. [http://dx.doi.org/10.1016/j.ajhg.2013.08.010] [PMID: 24094747]

[15] Baratz KH, Tosakulwong N, Ryu E, et al. E2-2 protein and Fuchs's corneal dystrophy. N Engl J Med 2010; $363(11)$ : 1016-24. [http://dx.doi.org/10.1056/NEJMoa1007064] [PMID: 20825314]

[16] Li YJ, Minear MA, Rimmler J, et al. Replication of TCF4 through association and linkage studies in late-onset Fuchs endothelial corneal dystrophy. PLoS One 2011; 6(4): e18044. [http://dx.doi.org/10.1371/journal.pone.0018044] [PMID: 21533127]

[17] Ołdak M, Ruszkowska E, Udziela M, et al. Fuchs endothelial corneal dystrophy: Strong association with rs613872 not paralleled by changes in corneal endothelial TCF4 mRNA level. BioMed Res Int 2015; 2015: 640234. [http://dx.doi.org/10.1155/2015/640234] [PMID: 26451375]

[18] Thalamuthu A, Khor CC, Venkataraman D, et al. Association of TCF4 gene polymorphisms with Fuchs' corneal dystrophy in the Chinese. Invest Ophthalmol Vis Sci 2011; 52(8): 5573-8.

[http://dx.doi.org/10.1167/iovs.11-7568] [PMID: 21659310]

[19] Wang KJ, Jhanji V, Chen J, et al. Association of transcription factor 4 (TCF4) and Protein Tyrosine Phosphatase, Receptor type G (PTPRG) with corneal dystrophies in southern Chinese. Ophthalmic Genet 2014; 35(3): 138-41. [http://dx.doi.org/10.3109/13816810.2013.804098] [PMID: 23758498]

[20] Nanda GG, Padhy B, Samal S, Das S, Alone DP. Genetic association of TCF4 intronic polymorphisms, CTG18.1 and rs17089887, with Fuchs' endothelial corneal dystrophy in an Indian population. Invest Ophthalmol Vis Sci 2014; 55(11): 7674-80. [http://dx.doi.org/10.1167/iovs.14-15297] [PMID: 25342617]

[21] Wieben ED, Aleff RA, Tosakulwong N, et al. A common trinucleotide repeat expansion within the transcription factor 4 (TCF4, E2-2) gene 
predicts Fuchs corneal dystrophy. PLoS One 2012; 7(11): e49083.

[http://dx.doi.org/10.1371/journal.pone.0049083] [PMID: 23185296]

[22] Mootha VV, Gong X, Ku HC, Xing C. Association and familial segregation of CTG18.1 trinucleotide repeat expansion of TCF4 gene in Fuchs' endothelial corneal dystrophy. Invest Ophthalmol Vis Sci 2014; 55(1): 33-42. [http://dx.doi.org/10.1167/iovs.13-12611] [PMID: 24255041]

[23] Xing C, Gong X, Hussain I, et al. Transethnic replication of association of CTG18.1 repeat expansion of TCF4 gene with Fuchs' corneal dystrophy in Chinese implies common causal variant. Invest Ophthalmol Vis Sci 2014; 55(11): 7073-8. [http://dx.doi.org/10.1167/iovs.14-15390] [PMID: 25298419]

[24] Vasanth S, Eghrari AO, Gapsis BC, et al. Expansion of CTG18.1 trinucleotide repeat in TCF4 is a potent driver of fuchs' corneal dystrophy. Invest Ophthalmol Vis Sci 2015; 56(8): 4531-6. [http://dx.doi.org/10.1167/iovs.14-16122] [PMID: 26200491]

[25] Nakano M, Okumura N, Nakagawa H, et al. Trinucleotide repeat expansion in the TCF4 gene in fuchs' endothelial corneal dystrophy in japanese. Invest Ophthalmol Vis Sci 2015; 56(8): 4865-9. [http://dx.doi.org/10.1167/iovs.15-17082] [PMID: 26218914]

[26] Foja S, Luther M, Hoffmann K, Rupprecht A, Gruenauer-Kloevekorn C. CTG18.1 repeat expansion may reduce TCF4 gene expression in corneal endothelial cells of German patients with Fuchs' dystrophy. Graefes Arch Clin Exp Ophthalmol 2017; 255(8): 1621-31. [http://dx.doi.org/10.1007/s00417-017-3697-7] [PMID: 28608272]

[27] Kuot A, Hewitt AW, Snibson GR, et al. TGC repeat expansion in the TCF4 gene increases the risk of Fuchs' endothelial corneal dystrophy in Australian cases. PLoS One 2017; 12(8): e0183719. [http://dx.doi.org/10.1371/journal.pone.0183719] [PMID: 28832669]

[28] Hurtley SM, Bole DG, Hoover-Litty H, Helenius A, Copeland CS. Interactions of misfolded influenza virus hemagglutinin with Binding Protein (BiP). J Cell Biol 1989; 108(6): 2117-26. [http://dx.doi.org/10.1083/jcb.108.6.2117] [PMID: 2738090]

[29] Ellgaard L, Helenius A. Quality control in the endoplasmic reticulum. Nat Rev Mol Cell Biol 2003; 4(3): $181-91$. [http://dx.doi.org/10.1038/nrm1052] [PMID: 12612637]

[30] Smith MH, Ploegh HL, Weissman JS. Road to ruin: Targeting proteins for degradation in the endoplasmic reticulum. Science 2011; 334(6059): 1086-90. [http://dx.doi.org/10.1126/science.1209235] [PMID: 22116878]

[31] Walter P, Ron D. The unfolded protein response: From stress pathway to homeostatic regulation. Science 2011; 334(6059): 1081-6. [http://dx.doi.org/10.1126/science.1209038] [PMID: 22116877]

[32] Rainbolt TK, Saunders JM, Wiseman RL. Stress-responsive regulation of mitochondria through the ER unfolded protein response. Trends Endocrinol Metab 2014; 25(10): 528-37

[http://dx.doi.org/10.1016/j.tem.2014.06.007] [PMID: 25048297]

[33] Lin JH, Lavail MM. Misfolded proteins and retinal dystrophies. Adv Exp Med Biol 2010; 664: 115-21. [http://dx.doi.org/10.1007/978-1-4419-1399-9_14] [PMID: 20238009]

[34] Halliday M, Mallucci GR. Targeting the unfolded protein response in neurodegeneration: A new approach to therapy. Neuropharmacology. 2014;76 Pt A:169-74

[http://dx.doi.org/10.1016/j.neuropharm.2013.08.034]

[35] Halliday M, Mallucci GR. Review: Modulating the unfolded protein response to prevent neurodegeneration and enhance memory. Neuropathol Appl Neurobiol 2015; 41(4): 414-27. [http://dx.doi.org/10.1111/nan.12211] [PMID: 25556298]

[36] Huang HC, Tang D, Lu SY, Jiang ZF. Endoplasmic reticulum stress as a novel neuronal mediator in Alzheimer's disease. Neurol Res 2015; 37(4): 366-74

[http://dx.doi.org/10.1179/1743132814Y.0000000448] [PMID: 25310352]

[37] Scheper W, Hoozemans JJ. The unfolded protein response in neurodegenerative diseases: A neuropathological perspective. Acta Neuropathol 2015; 130(3): 315-31.

[http://dx.doi.org/10.1007/s00401-015-1462-8] [PMID: 26210990]

[38] Jiang D, Niwa M, Koong AC. Targeting the IRE1 $\alpha$-XBP1 branch of the unfolded protein response in human diseases. Semin Cancer Biol 2015; 33: 48-56. [http://dx.doi.org/10.1016/j.semcancer.2015.04.010] [PMID: 25986851]

[39] Engler C, Kelliher C, Spitze AR, Speck CL, Eberhart CG, Jun AS. Unfolded protein response in fuchs endothelial corneal dystrophy: A unifying pathogenic pathway? Am J Ophthalmol. 2010;149(2):194-202 e2. [http://dx.doi.org/10.1016/j.ajo.2009.09.009]

[40] Jun AS, Meng H, Ramanan N, et al. An alpha 2 collagen VIII transgenic knock-in mouse model of Fuchs endothelial corneal dystrophy shows early endothelial cell unfolded protein response and apoptosis. Hum Mol Genet 2012; 21(2): 384-93. [http://dx.doi.org/10.1093/hmg/ddr473] [PMID: 22002996]

[41] Okumura N, Kitahara M, Okuda H, et al. Sustained activation of the unfolded protein response induces cell death in fuchs' endothelial corneal 
dystrophy. Invest Ophthalmol Vis Sci 2017; 58(9): 3697-707.

[http://dx.doi.org/10.1167/iovs.16-21023] [PMID: 28727885]

[42] Okumura N, Hashimoto K, Kitahara M, et al. Activation of TGF- $\beta$ signaling induces cell death via the unfolded protein response in Fuchs endothelial corneal dystrophy. Sci Rep 2017; 7(1): 6801. [http://dx.doi.org/10.1038/s41598-017-06924-3] [PMID: 28754918]

[43] Jurkunas UV, Rawe I, Bitar MS, et al. Decreased expression of peroxiredoxins in Fuchs' endothelial dystrophy. Invest Ophthalmol Vis Sci 2008; 49(7): 2956-63.

[http://dx.doi.org/10.1167/iovs.07-1529] [PMID: 18378575]

[44] Jurkunas UV, Bitar MS, Funaki T, Azizi B. Evidence of oxidative stress in the pathogenesis of fuchs endothelial corneal dystrophy. Am J Pathol 2010; 177(5): 2278-89.

[http://dx.doi.org/10.2353/ajpath.2010.100279] [PMID: 20847286]

[45] Azizi B, Ziaei A, Fuchsluger T, Schmedt T, Chen Y, Jurkunas UV. p53-regulated increase in oxidative-stress-induced apoptosis in Fuchs endothelial corneal dystrophy: A native tissue model. Invest Ophthalmol Vis Sci 2011; 52(13): 9291-7. [http://dx.doi.org/10.1167/iovs.11-8312] [PMID: 22064994]

[46] Bitar MS, Liu C, Ziaei A, Chen Y, Schmedt T, Jurkunas UV. Decline in DJ-1 and decreased nuclear translocation of Nrf2 in Fuchs endothelial corneal dystrophy. Invest Ophthalmol Vis Sci 2012; 53(9): 5806-13. [http://dx.doi.org/10.1167/iovs.12-10119] [PMID: 22836768]

[47] Ziaei A, Schmedt T, Chen Y, Jurkunas UV. Sulforaphane decreases endothelial cell apoptosis in fuchs endothelial corneal dystrophy: A novel treatment. Invest Ophthalmol Vis Sci 2013; 54(10): 6724-34. [http://dx.doi.org/10.1167/iovs.13-12699] [PMID: 24030461]

[48] Tuberville AW, Wood TO, McLaughlin BJ. Cytochrome oxidase activity of Fuchs' endothelial dystrophy. Curr Eye Res 1986 ; 5(12): 939-47. [http://dx.doi.org/10.3109/02713688608995175] [PMID: 3026733]

[49] Gottsch JD, Bowers AL, Margulies EH, et al. Serial analysis of gene expression in the corneal endothelium of Fuchs' dystrophy. Invest Ophthalmol Vis Sci 2003; 44(2): 594-9. [http://dx.doi.org/10.1167/iovs.02-0300] [PMID: 12556388]

[50] Benischke AS, Vasanth S, Miyai T, et al. Activation of mitophagy leads to decline in Mfn2 and loss of mitochondrial mass in Fuchs endothelial corneal dystrophy. Sci Rep 2017; 7(1): 6656. [http://dx.doi.org/10.1038/s41598-017-06523-2] [PMID: 28751712]

[51] Du J, Aleff RA, Soragni E, et al. RNA toxicity and missplicing in the common eye disease fuchs endothelial corneal dystrophy. J Biol Chem 2015; 290(10): 5979-90. [http://dx.doi.org/10.1074/jbc.M114.621607] [PMID: 25593321]

[52] Mootha VV, Hussain I, Cunnusamy K, et al. TCF4 Triplet repeat expansion and nuclear RNA foci in fuchs' endothelial corneal dystrophy. Invest Ophthalmol Vis Sci 2015; 56(3): 2003-11. [http://dx.doi.org/10.1167/iovs.14-16222] [PMID: 25722209]

[53] Tan DT, Dart JK, Holland EJ, Kinoshita S. Corneal transplantation. Lancet 2012; 379(9827): $1749-61$. [http://dx.doi.org/10.1016/S0140-6736(12)60437-1] [PMID: 22559901]

[54] Patel SV. Graft survival and endothelial outcomes in the new era of endothelial keratoplasty. Exp Eye Res 2012; 95(1): 40-7. [http://dx.doi.org/10.1016/j.exer.2011.05.013] [PMID: 21689649]

[55] Okumura N, Kinoshita S, Koizumi N. Cell-based approach for treatment of corneal endothelial dysfunction. Cornea 2014; 33(Suppl. 11): S37-41. [http://dx.doi.org/10.1097/ICO.0000000000000229] [PMID: 25188790]

[56] Ishino Y, Sano Y, Nakamura T, et al. Amniotic membrane as a carrier for cultivated human corneal endothelial cell transplantation. Invest Ophthalmol Vis Sci 2004; 45(3): 800-6.

[http://dx.doi.org/10.1167/iovs.03-0016] [PMID: 14985293]

[57] Mimura T, Yamagami S, Yokoo S, et al. Cultured human corneal endothelial cell transplantation with a collagen sheet in a rabbit model. Invest Ophthalmol Vis Sci 2004; 45(9): 2992-7. [http://dx.doi.org/10.1167/iovs.03-1174] [PMID: 15326112]

[58] Koizumi N, Sakamoto Y, Okumura N, et al. Cultivated corneal endothelial cell sheet transplantation in a primate model. Invest Ophthalmol Vis Sci 2007; 48(10): 4519-26. [http://dx.doi.org/10.1167/iovs.07-0567] [PMID: 17898273]

[59] Koizumi N, Okumura N, Kinoshita S. Development of new therapeutic modalities for corneal endothelial disease focused on the proliferation of corneal endothelial cells using animal models. Exp Eye Res 2012; 95(1): 60-7. [http://dx.doi.org/10.1016/j.exer.2011.10.014] [PMID: 22067130]

[60] Mimura T, Shimomura N, Usui T, et al. Magnetic attraction of iron-endocytosed corneal endothelial cells to Descemet's membrane. Exp Eye Res 2003; 76(6): 745-51. [http://dx.doi.org/10.1016/S0014-4835(03)00057-5] [PMID: 12742357]

[61] Mimura T, Yamagami S, Usui T, et al. Long-term outcome of iron-endocytosing cultured corneal endothelial cell transplantation with 
magnetic attraction. Exp Eye Res 2005; 80(2): 149-57.

[http://dx.doi.org/10.1016/j.exer.2004.08.021] [PMID: 15670793]

[62] Mimura T, Yamagami S, Yokoo S, et al. Sphere therapy for corneal endothelium deficiency in a rabbit model. Invest Ophthalmol Vis Sci 2005; 46(9): 3128-35 [http://dx.doi.org/10.1167/iovs.05-0251] [PMID: 16123411]

[63] Okumura N, Ueno M, Koizumi N, et al. Enhancement on primate corneal endothelial cell survival in vitro by a ROCK inhibitor. Invest Ophthalmol Vis Sci 2009; 50(8): 3680-7. [http://dx.doi.org/10.1167/iovs.08-2634] [PMID: 19387080]

[64] Okumura N, Sakamoto Y, Fujii K, et al. Rho kinase inhibitor enables cell-based therapy for corneal endothelial dysfunction. Sci Rep 2016; 6: 26113. [http://dx.doi.org/10.1038/srep26113] [PMID: 27189516]

[65] Okumura N, Koizumi N, Ueno M, et al. ROCK inhibitor converts corneal endothelial cells into a phenotype capable of regenerating in vivo endothelial tissue. Am J Pathol 2012; 181(1): 268-77. [http://dx.doi.org/10.1016/j.ajpath.2012.03.033] [PMID: 22704232]

[66] Okumura N, Kinoshita S, Koizumi N. Application of Rho kinase inhibitors for the treatment of corneal endothelial diseases. J Ophthalmol 2017; 2017: 2646904. [http://dx.doi.org/10.1155/2017/2646904] [PMID: 28751979]

[67] Nakagawa O, Fujisawa K, Ishizaki T, Saito Y, Nakao K, Narumiya S. ROCK-I and ROCK-II, two isoforms of Rho-associated coiled-coil forming protein serine/threonine kinase in mice. FEBS Lett 1996; 392(2): 189-93. [http://dx.doi.org/10.1016/0014-5793(96)00811-3] [PMID: 8772201]

[68] Riento K, Ridley AJ. Rocks: multifunctional kinases in cell behaviour. Nat Rev Mol Cell Biol 2003; 4(6): 446-56. [http://dx.doi.org/10.1038/nrm1128] [PMID: 12778124]

[69] Narumiya S, Tanji M, Ishizaki T. Rho signaling, ROCK and mDia1, in transformation, metastasis and invasion. Cancer Metastasis Rev 2009; 28(1-2): 65-76. [http://dx.doi.org/10.1007/s10555-008-9170-7] [PMID: 19160018]

[70] Okumura N, Koizumi N, Ueno M, et al. Enhancement of corneal endothelium wound healing by Rho-associated Kinase (ROCK) inhibitor eye drops. Br J Ophthalmol 2011; 95(7): 1006-9. [http://dx.doi.org/10.1136/bjo.2010.194571] [PMID: 21398412]

[71] Okumura N, Koizumi N, Kay EP, et al. The ROCK inhibitor eye drop accelerates corneal endothelium wound healing. Invest Ophthalmol Vis Sci 2013; 54(4): 2493-502. [http://dx.doi.org/10.1167/iovs.12-11320] [PMID: 23462749]

[72] Okumura N, Inoue R, Okazaki Y, et al. Effect of the Rho kinase inhibitor y-27632 on corneal endothelial wound healing. Invest Ophthalmol Vis Sci 2015; 56(10): 6067-74. [http://dx.doi.org/10.1167/iovs.15-17595] [PMID: 26393474]

[73] Koizumi N, Okumura N, Ueno M, Nakagawa H, Hamuro J, Kinoshita S. Rho-associated kinase inhibitor eye drop treatment as a possible medical treatment for Fuchs corneal dystrophy. Cornea 2013; 32(8): 1167-70. [http://dx.doi.org/10.1097/ICO.0b013e318285475d] [PMID: 23715376]

[74] Shah RD, Randleman JB, Grossniklaus HE. Spontaneous corneal clearing after Descemet's stripping without endothelial replacement. Ophthalmology 2012; 119(2): 256-60. [http://dx.doi.org/10.1016/j.ophtha.2011.07.032] [PMID: 21982414]

[75] Galvis V, Tello A, Miotto G. Human corneal endothelium regeneration. Ophthalmology 2012; 119(8): 1714-5 [http://dx.doi.org/10.1016/j.ophtha.2012.03.052] [PMID: 22858028]

[76] Bleyen I, Saelens IE, van Dooren BT, van Rij G. Spontaneous corneal clearing after Descemet's stripping. Ophthalmology 2013 ; $120(1)$ : 215. [http://dx.doi.org/10.1016/j.ophtha.2012.08.037] [PMID: 23283191]

[77] Moloney G, Petsoglou C, Ball M, et al. Descemetorhexis without grafting for fuchs endothelial dystrophy-supplementation with topical ripasudil. Cornea 2017; 36(6): 642-8. [http://dx.doi.org/10.1097/ICO.0000000000001209] [PMID: 28476048]

[78] Kim EC, Meng H, Jun AS. N-Acetylcysteine increases corneal endothelial cell survival in a mouse model of Fuchs endothelial corneal dystrophy. Exp Eye Res 2014; 127: 20-5. [http://dx.doi.org/10.1016/j.exer.2014.06.002] [PMID: 24952277]

[79] Kim EC, Meng H, Jun AS. Lithium treatment increases endothelial cell survival and autophagy in a mouse model of Fuchs endothelial corneal dystrophy. Br J Ophthalmol 2013; 97(8): 1068-73.

[http://dx.doi.org/10.1136/bjophthalmol-2012-302881] [PMID: 23759441]

[80] Kim EC, Toyono T, Berlinicke CA, et al. Screening and characterization of drugs that protect corneal endothelial cells against unfolded protein response and oxidative stress. Invest Ophthalmol Vis Sci 2017; 58(2): 892-900. [http://dx.doi.org/10.1167/iovs.16-20147] [PMID: 28159976]

[81] Okumura N, Minamiyama R, Ho LT, et al. Involvement of ZEB1 and Snaill in excessive production of extracellular matrix in Fuchs 
endothelial corneal dystrophy. Lab Invest 2015; 95(11): 1291-304.

[http://dx.doi.org/10.1038/labinvest.2015.111] [PMID: 26302187]

(C) 2018 Okumura et al.

This is an open access article distributed under the terms of the Creative Commons Attribution 4.0 International Public License (CC-BY 4.0), a copy of which is available at: (https://creativecommons.org/licenses/by/4.0/legalcode). This license permits unrestricted use, distribution, and reproduction in any medium, provided the original author and source are credited. 